\title{
Perubahan Moral Peserta Didik Melalui Lingkungan Sekolah
}

\author{
Ichwani Siti Utami ${ }^{\mathrm{a}, 1 *}$, Aditya Saputra ${ }^{\mathrm{b}, 2}$ \\ a,b Pendidikan Pancasila dan Kewarganegaraan, \\ Fakultas Keguruan dan Ilmu Pendidikan, Universitas Pamulang, Tangerang Selatan \\ ${ }^{1}$ dosen00655@unpam.ac.id; 2adityasaputra1205@gmail.com \\ *korespondensi penulis
}

Naskah diterima: 12-09-19, direvisi: 23-09-19, disetujui: 30-09-19

DOI: http://dx.doi.org/10.32493/jpkn.v6i2.y2019.p95-104

\begin{abstract}
Abstrak
Permasalahan pada saat ini lingkungan sekolah terbatas dalam mengawasi peserta didik saat sepulang sekolah. Interaksi di luar sekolah dan penggunaan gadget berlebihan serta keterbatasan orang tua dalam mengakses media elektronik yang digunakan peserta didik saat berada di rumah. Penelitian ini bertujuan untuk membuktikan secara empiris dengan menganalisis lingkungan sekolah dalam pembentukan moral siswa di kelas $\mathrm{X}$ Madrasah Aliyah (MA) Al-Amanah Al-Gontory, Tangerang Selatan. Penelitian menggunakan pendekatan kuantitatif, karena dalam penelitian ini bahan yang di sajikan menggunakan angka-angka. Hasil penelitian menunjukkan bahwa penggunaan gadget pada peserta didik dapat dikurangi, namun kita harus sabar karena ada tahapan dalam proses pembiasaan, yaitu dengan menggantinya dengan kegiatan yang lebih bermanfaat. Saran dari penelitian ini yaitu pendekatan secara intensif terhadap peserta didik yang memiliki karakter khusus berupa diskusi, agar mereka merasa aman dan nyaman dengan lingkungan yang baru di boarding school.
\end{abstract}

Kata-kata kunci: lingkungan sekolah; moral siswa; siswa sekolah menengah atas

\section{Abstract}

The problem at this time is the school environment is limited in supervising students after school. Interaction outside of school and excessive use of gadgets and limitations of parents in accessing electronic media used by students while at home. This study aims to prove empirically by analyzing the School Environment in the formation of Moral Students in Class X MA. Al-Amanah Al-Gontory, South Tangerang. In this approach the researcher uses a quantitative approach, because in this study the material presented uses numbers. The results of this study from the data that has been analyzed turns out that the school environment on the use of gadgets on students can be reduced, but we must be patient because there are stages in the habituation process. namely by replacing them with more useful activities. The suggestion from this research is an intensive approach to students who have a special character in the form of discussion, so that they feel safe and comfortable with the new environment at the Boarding School.

Keywords: school environment ; students' moral; high school students 


\section{Pendahuluan}

Pendidikan disediakan dengan tujuannya terletak pada salah satu hal yang paling penting untuk menyiapkan sebuah masa depan untuk anak bangsa pada di zaman globalisasi ini. Pendidikan bisa diraih dengan berbagai macam cara salah satunya pendidikan di sekolah. Dengan adanya pendidikan merupakan salah satu upaya untuk mempersiapkan bibit-bibit sumber daya manusia sebagai salah satu peningkatan kualitasnya. Pendidikan dan bimbingan tidak sepenuhnya tergantung pada lingkungan sekolah saja, namun juga berkaitan dengan lingkungan dan kondisi sekitarnya. Dalam pencapaian tujuna pendidikan perlu adanya dukungan dari semua pihak, yaitu seperti yang kita ketahui adanya tri pusat dalam pendidikan adalah: pendidikan di berlangsung di sekolah sebagai pendidikan formal, dalam lingkungan keluarga dan masyarakat sebagai pendidikan non formal. Sekolah sebagai lembaga pendidikan formal kegiatan belajar mengajar merupakan fungsi pokok dalam mewujudkan tujuan institusioanal.

Tujuan pendidikan nasional adalah untuk merumuskan mengenai kualitas manusianya yang harus lebih di kembangkan lagi oleh setiap satuan pendidikan. Maka rumusan dari tujuan pendidikan nasional itu menjadi dasar dalam mengembangkan pendidikan dan budaya serta karakter bangsanya. Dalam hal ini, terdapat istilah pendidikan dalam sebuah kebijakan yang tertuang dalam UU Sisdiknas No. 20 tahun 2003 pasal 1 dinyatakan bahwa "Pendidikan adalah usaha sadar dan terencana untuk mewujudkan suasana belajar dalam proses pembelajaran agar peserta didik secara aktif mengembangkan potensi dirinya untuk memiliki kekuatan spiritual keagamaan, pengendalian diri, kepribadian, kecerdasan, akhlak mulia, serta keterampilan yang di butuhkan dirinya, masyarakat, bangsa dan negara.

Untuk mewujudkan UU Sisdiknas No. 20 tahun 2003 pasal 1 salah satunya yaitu dengan memperhatikan pembentukan moral yang berupa sikap atau tindakan yang dilakukan oleh peserta didik. Tindakan moral peserta didik sangat dipengaruhi dengan segala sesuatu yang ada di sekitarnya. Lingkungan sosial peserta didik yang terdiri dari lingkungan keluarga, sekolah, dan lingkungan sekitar perlu difasilitasi dengan sarana dan prasana yang mendukung pembentukan suasana yang kondusif. Tindakan moral dalam kehidupan sehari-hari merupakan pembelajaran dalam pembentukan akhlak yang baik untuk peserta didik.

Untuk membentuk moral peserta didik sangat dipengaruhi dari beberapa faktor lingkungan yaitu faktor lingkungan masyarakat, lingkungan keluarga dan lingkungan sekolah. Lingkungan keluarga menjadi awal pembentukan moral peserta didik karena dari keluarga awal mereka diberikan pengetahuan dan pendidikan oleh orang tua dan anggota keluarga lainnya, serta segala sesuatu apapun yang mereka lihat dan rasakan. Keluar dari rumah mereka akan berada di lingkungan sekolah yang merupakan lingkungan pendidikan dengan berbagai unsur pendukung di dalamnya. 
Menurut Beni Ahmad Saebani dan Hendra Akhdiyat (2009: 262) lingkungan adalah sebuah wadah yang di dalamnya disediakan ruang dan waktu untuk teciptanya sebuah eksistensi manusia. Faktor utama yang mempengaruhi perkembangan jiwa serta keberhasilan hasil belajar anak yaitu ditentukan dari lingkungan sekolah. Lingkungan yang dimaksud adalah lingkungan sekolah, keluarga dan masyarakat lingkungan sekolah diyakini berperan penting dalam membentuk moral peserta didik selain lingkungan keluarga, terutama untuk tingkatan SMP dan SMA, Lingkungan sekolah tersebut mempunyai faktor yang dapat mempengaruhi pembentukan moral peserta didik yaitu di antaranya yang perlu diperhatikan adalah kematangan peserta didik, keadaan fisik peserta didik, kehidupan sekolah, guru, staf, dan kurikulum sekolah. karena secara psikologis pada masa itulah seseorang masih berusaha untuk menemukan jati dirinya, pada masa itu juga seseorang sangat rawan sekali dengan hal-hal yang mungkin tidak baik bagi dirinya.

Lingkungan sekolah bukan hanya menerapkan di bidang pendidikan saja yang diajarkan tetapi juga nilai-nilai moral dan etika dalam berperilaku serta pendidikan yang berkarakter yang dibentuk melalui unsur unsur di dalamnya. Yang menjadi permasalahan pada saat ini lingkungan sekolah terbatas dalam mengawasi peserta didik saat sepulang sekolah. Interaksi di luar sekolah dan penggunaan gadget berlebihan serta keterbatasan orang tua dalam mengakses media elektronik yang digunakan peserta didik saat berada di rumah. Hal ini berpotensi berdampak negatif terhadap peserta didik. Berdasarkan peristiwa tersebut diperlukan pengawasan yang lebih optimal yaitu seperti sekolah berbentuk boarding school yaitu sebuah sistem yang disediakan oelh pihak sekolah berbentuk asrama dimana peserta didik dan tenaga pengajar serta pengelola sekolah tinggal di asrama yang sama dalam lingkungan sekolah dalam kurun waktu tertentu. Boarding School adalah sekolah yang memiliki asrama dimana para peserta didik hidup dan belajar secara total di lingkungan sekolah. Oleh karena arena itu segala jenis kebutuhan hidup dan kebutuhan belajar disediakan oleh sekolah.

MA Al- Amanah Al-Gontory adalah salah satu sekolah berbentuk boarding school atau pondok pesantren di daerah Tangerang Selatan tepatnya di Perigi Baru, Pondok Aren. Sekolah yang berbentuk asrama dan peserta didiknya disebut santri. Proses pendidikan dan pembelajaran tidak hanya melalui jam pelajaran sekolah tetapi juga dilaksanakan di luar jam sekolah, serta pengajar yang biasa disebut ustadz dan ustadzah tinggal di dalam asrama. Berdasarkan data hasil ujian lisan (Oral Examination) dan praktek tes masuk peserta didik baru oleh bagian konseling di MA Al-Amanah Al-Gontory, pertama bentuk penerapan sila pertama yaitu Ketuhanan Yang Maha Esa berupa kegiatan spiritual sangatlah kurang, kedua pada masa orientasi calon pesertaarr didik baru masih membawa kebiasaan saat masih di rumah seperti berkata kasar, 
kurang berakhlak dan beretika baik saat menghadapi ustadz dan ustadzah, ketiga masih ada calon peserta didik baru yang berusaha untuk keluar dari wilayah sekolah karena kebiasaan mereka bermain saat sepulang sekolah dan ketergantungan pada penggunaan media elektronik (Gadget) berlebihan sebelumnya.

Dari keterangan di atas dapat dikatakan pengawasan yang terbatas memberi peluang peserta didik bebas berinteraksi dengan siapapun dan mengakses media elektronik tanpa batasan berdampak pada pembentukan moral yang kurang baik. Dengan adanya sekolah yang menggunakan sistem boarding school bertujuan untuk mengurangi dan lebih mengawasi para peserta didik dari hal-hal yang berpotensi merusak moral mereka, karena pada hakikatnya pendidikan bukan hanya saat KBM di kelas, melainkan apa yang dilihat, dirasakan, dan didengarkan. Dengan lingkungan yang berasaskan sila yang pertama, sekolah (Boarding School) menekankan kegiatan spiritual yang di dalamnya terkandung akhlakul karimah bisa juga disebut moral yang baik dengan berbagai unsur pendukung di dalamnya.

Berdasar latar belakang masalah di atas terdapat rumusan masalah yaitu Apakah ada pengaruh lingkungan sekolah terhadap pembentukan Moral siswa? melihat dari judul penelitian yang diteliti ,merujuk pada penelitian yang sudah dilakukan oleh peneliti yang lain berhubungan dengan variabel yang diambil yaitu lingkungan sekolah. Hasil penelitian yang diperoleh ternyata terdapat pengaruh lingkungan sekolah terhadap siswa. Pembatasan masalah pada penelitian ini dibatasi pada lingkungan sekolah (boarding School) terhadap moral siswa di Kelas X MA Al-Amanah AlGontory. Hipotesis penelitian ini yaitu diduga terdapat pengaruh lingkungan sekolah yang signifikan terhadap moral peserta didik di Kelas X MA Al-Amanah Al-Gontory.

Penelitian ini bertujuan untuk membuktikan bahwa data yang telah diambil dan diolah terdapat Pengaruh Lingkungan Sekolah terhadap Pembentukan Moral Siswa di Kelas X MA. Al-Amanah Al-Gontory, Tangerang Selatan. Penelitian ini diharapkan bermanfaat untuk dapat membuat peserta didik dapat membatasi pergaulan yang berpotensi merusak moral di lingkungan sekolah, membentuk moral peserta didik dengan berbagai macam kegiatan yang positif, dapat lebih meningkatkan pengawasan terhadap peserta didik di lingkungan sekolah, menambah pengetahuan mengenai pergaulan anak usia remaja di masa kini, meningkatkan kualitas pendidikan melalui peningkatan pembentukan moral peserta didik, meningkatkan kedisiplinan dalam rangka mewujudkan lingkungan sekolah yang baik dan sehat.

\section{Metode}

Penelitian ini dilaksanakan di MA Pondok Pesantren Al-Amanah Al Gontory pada semester genap tahun ajaran 2018/2019. Dalam pendekatan ini peneliti menggunakan pendekatan kuantitatif, karena dalam penelitian ini bahan yang di sajikan menggunakan angka-angka. 
Penelitian Kuantitatif adalah pendekatan penelitian yang banyak di tuntut menggunakan angka, mulai dari pengumpulan datanya, penjelasan dari data yang diolahnya serta penampilan pada hasil data tersebut. Metode yang digunakan dalam penelitian ini adalah metode penelitian lapangan (Field Research) dengan menggunakan pendekatan kuantitatif dimana peneliti melakukan penelitian langsung kelapangan untuk mencari data dari responden.

Populasi dalam penelitian ini adalah peserta didik kelas X MA Ponpes AlAmanah Al-Gontory. Tahun Pelalajaran 2018/2019, yang berjumlah 144 siswa. peneliti mengambil $10 \%$ dari total populasi (144 orang) untuk dijadikan sampel penelitian. Artinya siswa kelas $\mathrm{X}$ MA Ponpes Al-Amanah Al-Gontory. Tahun Pelalajaran 2018/2019 diambil sampel sebanyak $10 \%$ dari jumlah masing-masing kelas dengan cara simple random sampling. Sehingga diperoleh jumlah sampelnya adalah 60 orang. Secara rinci peyebaran jumlah populasi dan sampel siswa di ambil dari kelas siswa kelas X MA Ponpes Al-Amanah AlGontory.

Teknik ini digunakan untuk memperoleh data tentang pengaruh lingkungan sekolah (Boarding school) terhadap moral peserta didik. Skala pengukuran untuk data ini adalah interval sehingga kuisioner yang digunakan berbentuk semantic differential. Teknik angket atau kuisioner teknik pengumpulan data dengan cara membuat pertanyaan atau pernyataan yang diajukan kepada responden dengan maksud menjaring data dan informasi langsung dari responden yang bersangkutan. Sasaran angket adalah siswa kelas X MA Ponpes Al - Amanah Al - Gontory tahun Pelalajaran 2018/2019. Penelitian ini menggunakan skala pengukuran yang digunakan Skala Likert. Skala Likert digunakan untuk mengukur sikap. Pendapat dan persepsi seseorang atau sekelompok orang tentang fenomena sosial. Untuk mengungkap berapa besar pengaruh lingkungan sekolah (Boarding School) terhadap moral peserta didik. Pengukuran skalalikert dalam bentuk angket pernyataan dengan empat kategori jawaban yaitu (SL) Selalu (SR) Sering (KD) Kadang-kadang (TP) Tidak Pernah.

Data yang nanti akan diperoleh dari angket, kemudian dipilih dan disusun. Setelah itu, dilakukan klasifikasi data, yaitu menggolongkan data berdasarkan katagori tertentu, sesuai dengan permasalahan-permasalahan yang dibuat berdasarkan analisis variable.

\section{Hasil dan Pembahasan}

Peneliti akan mendeskripsikan data yang diperoleh dari hasil penelitian tentang pengaruh lingkungan sekolah (boarding school) terhadap moral peserta didik dari setiap variabel yang diperoleh dari hasil penyebaran angket/kuisioner. Adapun deskripsi data variabel lingkungan sekolah dan moral peserta didik adalah sebagai berikut.

Berdasarkan penelitian yang dilakukan mengenai variabel Lingkungan Sekolah (Boarding School) diperoleh nilai dengan skor tertinggi 99, skor terendah 
Jurnal Pendidikan Kewarganegaraan

Vol. 6 No. 2 September 2019
Journal of Civics and Education Studies p-ISSN 2302-0865 | e-ISSN 2621-346X
30, rata-rata (mean) 8,1, nilai tengah (median) 76,9, modus (mode) 78,0, Simpangan Baku 30,56, dan varians 934,17.

\begin{tabular}{llll}
\hline \multirow{2}{*}{ No. } & Kelas & \multicolumn{2}{c}{ Frekuensi } \\
\cline { 3 - 4 } & Interval & Absolut & Relatif \\
\hline 1 & $30-39,9$ & 3 & 5,00 \\
2 & $40,9-50,8$ & 3 & 5,00 \\
3 & $51,8-61,7$ & 3 & 5,00 \\
4 & $62,7-72,6$ & 14 & 23,33 \\
5 & $73,6-83,5$ & 18 & 30,00 \\
6 & $84,5-94,4$ & 14 & 23,33 \\
7 & $95,4-99$ & 5 & 8,33 \\
Total & & 60 & 100,00 \\
\hline
\end{tabular}

Tabel 1. Distribusi Lingkungan Sekolah (Boarding School)

Berdasarkan penelitian yang dilakukan mengenai Moral Peserta didik, diperoleh nilai dengan skor tertinggi 100, skor terendah 37, rata-rata (mean)8,3, nilai tengah (median) 85,6, modus (mode) 85,80, varians 959,25, dan Simpangan Baku 30,90.

\begin{tabular}{llll}
\hline \multirow{2}{*}{ No. } & \multirow{2}{*}{$\begin{array}{l}\text { Kelas } \\
\text { Interval }\end{array}$} & \multicolumn{2}{c}{ Frekuensi } \\
\cline { 3 - 4 } & & Absolut & Relatif \\
\hline 1 & $37-46$ & 2 & 3,33 \\
2 & $47-56$ & 4 & 6,67 \\
3 & $57-66$ & 8 & 13,33 \\
4 & $67-76$ & 14 & 23,33 \\
5 & $77-86$ & 18 & 30,00 \\
6 & $87-96$ & 9 & 15,00 \\
7 & $97-100$ & 5 & 8,33 \\
\multicolumn{2}{l}{ Total } & 60 & 100,00 \\
\hline
\end{tabular}

Tabel 2. Distribusi Moral Peserta Didik.

Berdasarkan penelitian yang dilaksanakan di kelas X MA. Al- Amanah Al Gontory, Tangerang Selatan tentang Pengaruh Lingkungan Sekolah (Boarding School) terhadap Moral Peserta Didik. Dengan menggunakan data penelitian berupa angket dari masing-masing variabel yaitu Lingkungan Sekolah
(Boarding School) (X) dan Moral Peserta Didik (Y). Adapun hasil penelitian yang diperoleh sebagai berikut. Menggunakan pengujian persayaratan Analisis yang pertama dengan menggunakan Uji normalitas, Uji normalitas bertujuan untuk melihat besaran data yang akan dianalisis, apakah memiliki distribusi yang normal atau tidak. Berikut hasil perhitungan uji normalitas dengan $\mathrm{Uji}$ Liliefors dari hasil perhitungan tersebut ditemukan sebuah kesimpulan besaran data yang dianalisis untuk variabel $\mathrm{x}$ dan $\mathrm{y}$ berdistribusi normal. Selanjutnya dengan menggunakan uji homogenitas data yang diperoleh dari hasil pengujian dinyatakan data variabel $\mathrm{x}$ dan $\mathrm{y}$ homogen. Selanjutnya dilakukan pengujian hipotesis Perhitungan hipotesis terlebih dahulu dilakukan perhitungan koefisien kolerasi, dengan menghitung koefisien kolerasi antara Lingkungan Sekolah (Boarding School) dengan Moral Peserta didik ,dengan rumus korelasi product momen yang juga digunakan untuk menghitung persamaan regresi dari hasil perhitungan didapat sebuah jawaban hipotesis yaitu Ho ditolah dan $\mathrm{Ha}$ diterima artinya terdapat pengaruh antara lingkungan sekolah dengan moral peserta didik. Kemudian, pengujian keberartian hubungan dihitung dengann uji $t$ berdasarkan hasil pengujian signifikansi koefisien korelasi, terdapat hubungan yang positif dan nilai koefisien korelasi antara variabel $\mathrm{X}$ dan variabel $\mathrm{Y}$.

Berdasarkan analisis data, diketahui terdapat Pengaruh yang sedang antara Lingkungan Sekolah (Boarding School) dengan Moral Peserta didik, yaitu dengan 
melihat dari kriteria kolerasi koefisien besar $r$ sebagai berikut.

\begin{tabular}{ll}
\hline Nilai $\mathbf{r}$ & Tingkat Hubungan \\
\hline 0 & Tidak ada korelasi \\
$0,01-0,20$ & Sangat rendah \\
$0,20-0,40$ & Rendah \\
$0,40-0,70$ & Sedang \\
$0,70-0,90$ & Kuat/Tinggi \\
$0,90-1,00$ & Sangat Kuat/SangatTinggi \\
\hline
\end{tabular}

Tabel 3. Interpretasi Nilai (r)

Apabila dikonsultasikan pada tabel diatas maka angka $r(0,684)$ yang berada antara 0,40 - 0,70. Dengan demikian, dapat dikategorikan ke dalam kolerasi sedang. Untuk itu, dapat dikatakan terdapat pengaruh yang sedang antara pengaruh lingkungan sekolah (boarding school) terhadap moral peserta didik. Koefisien determinasi $\left(\mathrm{r}^{2}\right)$ sebesar $47 \%$ menunjukkan bahwa Moral Peserta Didik ditentukan oleh variabel Lingkungan Sekolah sebesar 47\%, sedangkan $53 \%$ dari faktor lain.

Setelah dilakukan pengujian hipotesis, dimana hipotesis yang dikemukakan dalam penelitian ini adalah terdapat Pengaruh Lingkungan Sekolah (Boarding School) terhadap Moral Peserta Didik dapat diterima, karena hipotesis statistik menunjuk kepada penerimaan hipotesis penelitian. Dalam penelitian yang telah dilakukan oleh peneliti dapat dikatakan bahwa pengujian hipotesis yang telah dibuktikan berhasil, karena terdapat hubungan sedang antara variabel $\mathrm{X}$ dan $\mathrm{Y}$ yaitu antara Lingkungan Sekolah (Boarding School) dengan Moral Peserta didik.

Namun dalam praktek penelitiannya masih banyak keterbatasan yang dihadapi oleh peneliti, yaitu keterbatasan waktu yang digunakan dalam penelitian, baik itu dalam mencari sampel atau yang lainnya. Kegiatan peserta didik yang begitu padat membuat peneliti harus menyesuaikan kegiatan di dalam Boarding School. Kelas yang terbagi berdasarkan gender peserta didik membuat peneliti membutuhkan pendampingan oleh ustadz atau ustadzah saat melakukan penyebaran angket dan proses penelitian lainnya.

Instrumen dalam penelitian yang disusun dan digunakan sudah disesuaikan dengan variabel-variabel yang akan diteliti. Walaupun banyak instrumen, peneliti juga harus menyaring instrumen yang sesuai saja, dan yang berkaitan dengan variabel penelitiannya. Ditambah dengan kegiatan dan peraturan yang diterapkan oleh sekolah Boarding School sangat berbeda dengan sekolah pada umumnya. Sehingga di awalnya banyak instrumen yang harus disusun kembali agar sesuai dengan variabel-variabel yang diteliti di lingkungan sekolah Boarding School. Pada penelitain ini, peneliti hanya membahas Pengaruh Lingkungan Sekolah (Boarding School) terhadap Moral Peserta didik. Walaupun banyak factor lain yang mempengaruhi pembentukan moral peserta didik, seperti kurikulum sekolah, lingkungan keluarga, dan lingkungan sekitar rumah.

Berdasarkan hasil penelitian ini bisa terlihat bahwa lingkungan sekolah bisa memperngaruhi terhadap moral siswa bisa kita lihat dari definisi Lingkungan sekolah terdiri atas dua kata yaitu, lingkungan dan sekolah. Menurut Kamus Besar Bahasa Indonesia lingkungan adalah "daerah (kawasan dan sebagainya) yang termasuk 
di dalamnya". Lembaga pendidikan, yang kita sebut kali ini sekolah seharusnya dalam kapasitas yang ada dapat mengambil alih fungsi-fungsi transmisi nilai di dalam keluarga dan masyarakat. Tentu saja, sehingga fungsi tersebut tidak seluruhnya dapat dibebankan kepada sekolah, karena adanya berbagai keterbatasan yang ada (Sairin, 2003:8). Diperlukannya pengawasan guru dengan tujuan untuk meningkatkan kecerdasan serta pembentukan moral dan karakter peserta didik agar menjadi individu yang lebih berkualitas tentunya hal ini perlu diperhatikan pada lembaga itu sendiri. Sekolah adalah suatu lembaga yang didirikan untuk proses pembelajaran peserta didik. Sekolah merupakan sarana yang sengaja dirancang untuk melaksanakan pendidikan, faktor dari kemajuan teknologi pun keluarga tidak mungkin dapat memenuhi kebutuhan anak tanpa dibantu oleh pihak yang berkompeten dalam hal tersebut. Semakin canggih teknologi pun mempengaruhi maju nya pemikiran masyarakat oleh karena semakin penting peranan sekolah dalam mempersiapkan generasi muda sebelum masuk ke dalam proses pembangunan masyarakat itu. Dengan hal tersebut sekolah perlu menyikapi bahwa sekolah merupakan sebagai pusat pelaksanaan pendidikan mampu melaksanakan pendidikan secara optimal yaitu mengembangkan kemampuan meningkatkan mutu kehidupan dan martabat bangsa Indonesia. Jika melihat dari ruang lingkup lingkungan pada penelitian ini membahas pada lingkungan khusus yaitu lingkungan sekolah boarding school, boarding school menurut Baktiar (2012) adalah sebuah tempat yang sudah tersusun sebuah sistem yaitu berupa sistem asrama dimana peserta didik beserta tenaga pengajar tinggal berada dalam kurun waktu tertentu. Boarding School adalah merupakan sekolah yang memiliki sebuah tempat yang dinamakan asrama untuk dijadikan tempat peserta didik hidup dan belajar secara fokus dan total dilingkungan sekolah.

Ditinjau dari karakteristik sebuah sistem pendidikan sekolah (Boarding School) bisa terlihat dari segi sosial yaitu sebuah sistem boarding school.

Melihat dari karakteristik dari sistem pendidikan Boarding School terlihat dari segi sosial yaitu sistem sekolah ini memisahkan anak dari lingkungan dari berbagai unsur dan cenderung kurang baik. lingkungan sekolah ini dan asrama dibangun suatu lingkungan sosial yang relatif homogen yakni teman sebaya dan para guru pembimbing. Homogen dalam tujuan untuk menuntut ilmu sebagai sarana mengejar cita-cita. Selanjutnya dari segi ekonomi, boarding school memberi layanan yang sangat prima sehingga menuntut biaya yang cukup tinggi.

Oleh karena itu harapan dari sistem ini peserta didik benar terlayani dengan baik melalui berbagai layanan dan fasilitas dan karakteristik yang terakhir yaitu dari segi semangat religius, boarding school menjanjikan pendidikan yang simbang antara kebutuhan jasmani dan kebutuhan rohani, intelektual, dan spiritual. Diharapkan lahir siswa yang tangguh secara keduniaan dengan ilmu dan 
teknologi serta siap secara iman dan amal sholeh. Dengan hadirnya lingkungan sekolah tersebut harapan dari masyarakat agar tercipta sebuah pembentukan ahlak yang baik karena didukung oleh sebuah fasilitas khusus dengan ditinjau dari segi ekonomi sesuai penjelasan di atas. Harapan masyarakat yang dimaksud pada paparan di atas berhubungan dnegan penelitian ini yaitu pada tingkah laku atau moral siswa dijelaskan pada sebuah pendapat para ahli yang dibuat menjadi sebuah kesimpulan bahwa moral adalah tingkah laku atau akhlak seseorang yang mencerminkan orang dapat dilihat baik buruknya itu dari etika mereka dan juga bagaimana mereka dapat menjalankan aturan atau norma-norma yang berlaku sesuai dengan tempat mereka tinggal atau lingkungan sekitarnya. Faktor utama dalam pembentukan moral siswa tergantung pada tempat tinggal atau lingkungan sekitarnya. moral atau akhlak itu sesuatu perbuatan yang berkaitan denagn tingkah laku seseorang yang menentukan baik buruknya perbuatan sesuai dengan norma-norma yang berlaku di tempat mereka tinggal. Siswa yang terbentuk perilaku atau moral yang baik tentunya dipengaruhi dari lingkungan baik. Lingkungan yang baik didominasi dari nilai agama yang difasilitasi dengan baik dan terprogram.

\section{Kesimpulan}

Dengan adanya penelitian ini yang menggunakan angket ternyata pengurangan terhadap penggunaan gadget pada peserta didik dapat dikurangi, namun kita harus sabar karena ada tahapan dalam proses pembiasaan. Yaitu dengan menggantinya dengan kegiatan yang lebih bermanfaat. Walaupun memang masih terdapat peserta didik yang kurang sopan terhadap gurunya, akan tetapi sesuai dengan prosedur dan pendekatan lingkungan sekolah (boarding school) yang lebih intensif maka sedikit demi sedikit mereka dapat bersikap lebih baik terhadap lingkungan sekitar. Cara mengurangi pelanggaran yang ada di sekolah (boarding school) adalah dengan memberi sanksi yang tegas tetapi berisikan edukasi dan religi (Keagamaan), sehingga secara tidak langsung memberikan efek jera yang di dalamnya terdapat pendidikan dan pembiasaan yang positif. 4. Berdasarkan hasil perhitungan, di atas maka angka $\mathrm{r}(0,684)$ yang berada antara 0,40 - 0,70. Dengan demikian, dapat dikategorikan ke dalam korelasi sedang. Jadi dengan adanya penelitian ini, terbukti bahwa memang terdapat pengaruh pengaruh lingkungan sekolah (boarding school) terhadap moral peserta didik. Antara variabel $\mathrm{X}$ dan $\mathrm{Y}$ pengaruhnya adalah sebesar $47 \%$.

Koefisien determinasi $\left(\mathrm{r}^{2}\right)$ sebesar $47 \%$ menunjukkan bahwa pengaruh antara Lingkungan Sekolah (boarding school) terhadap Moral Peserta didik sebesar $47 \%$ dan $53 \%$ dari faktor lain. Setelah dilakukan pengujian hipotesis, dimana hipotesis yang dikemukakan dalam penelitian ini adalah terdapat Pengaruh Lingkungan Sekolah (boarding school) terhadap Moral Peserta didik dapat diterima, karena hipotesis statistik menunjuk kepada penerimaan hipotesis penelitian. 
Berdasarkan hasil penelitian terdapat beberapa hal peneliti sarankan antara lain lingkungan sekolah (boarding school) adalah salah satu bentuk sekolah yang berbeda dengan sekolah umum lainnya dalam segi penerapan disiplin dan jam pelajaran, sehingga banyak peserta didik baru yang cukup perlu adaptasi dalam melaksanakannya. Dalam hal ini pihak sekolah (boarding school) harus dapat membuat tata tertib beserta hukuman bagi peserta didik baru yang melanggar secara bertahap tidak langsung sepenuhnya seperti peserta didik yang lama, agar tidak membuat peserta didik baru berfikir peraturan di Boarding School itu sebuah tekanan melainkan sebuah proses untuk lebih baik. Sebagai pendidik sekaligus pengganti peran orang tua peserta didik di lingkungan sekolah (boarding school) para guru (ustadz dan ustadzah) harus dapat menciptakan suasana yang kondusif. Yaitu dengan pendekatan secara intensif terhadap peserta didik yang memiliki karakter khusus berupa diskusi, agar mereka merasa aman dan nyaman dengan lingkungan yang baru. Sehingga (boarding school) dapat menjadi solusi pembentukan moral yang baik bagi peserta didik tersebut, bukan justru membuat moral peserta didik lebih rusak ketika tidak dapat mengikuti aturan sekolah dan akhirnya memutuskan untuk keluar dari lingkungan sekolah (boarding school).

\section{Referensi}

Ghozali, A. terjemah: Rifai, M. (1986). Akhlak seorang muslim, Semarang: Wicaksana,. Cet ke-1.

Saebani, A., Beni., \& Akhdiyat. (2009). Ilmu Pendidikan Islam 1. Bandung: CV. Pustaka Setia.

Baktiar. (2012) Boarding School dan Peranannya dalam pendidikan Islam,. (Online).(http://bhakti-

ardi.blogspot.com/2012/07/boardingschool-dan-perananannya-dalam

08.html, diakses tanggal 16 Maret 2019 jam 13.00 wib.

Coles, R. (2000). Menumbuhkan Kecerdasan Moral pada Anak. Alih Bahasa: $\mathrm{T}$ Hermaya. Jakarta: Gramedia Pustaka Utama.

Departemen Pendidikan Dan Kebudayaan, Kamus Besar Bahasa Indonesia, ( Jakarta: Balai Pustaka).

Derek, G., \& Law, S. (2005). Improving Learning Professional Practice in Secondary Schools. Jakarta: Grasindo.

Kurtines, W.W \& Gerwitz, J.L. (1992). Moralitas, Perilaku Moral, dan Perkembangan Moral. Penerjemah: M.I. Soelaeman. Jakarta: UI Press.

Sjafri, S. (2003). Kultur Sekolah dalam Era Multikultural. Makalaah Seminar Peningkatan Kualitas Pendidikan Melalui Pengembangan Kultur Sekolah, Pascasarjana, UNY.

Sugiyono. (2011). Metode Penelitian Kuantitatif, Kualitatif dan R\&D. Bandung. Alfabeta.

Undang-undang Nomor 20 Tahun 2003, tentang SISDIKNAS.

Darajat, Z. (2008) Ilmu Pendidikan Islam. Jakarta: Bumi Aksara. cet VII. 